\title{
Social Trust as an Intangible Condition for the Quality of Life: Considering After-Pandemic New Norms
}

\author{
Julia P. Bayer
}

Russian Presidential Academy of National Economy and Public Administration (North-West Institute of Management, Branch of RANEPA), Saint-Petersburg, Russian Federation; juliabayer@yandex.ru

\begin{abstract}
The article considers such a social phenomenon as social trust, the degree of knowledge of this phenomenon. The author gives a definition of social trust. Social trust is considered as one of the factors of quality of life. The transformation of social trust from an industrial society to the contemporary stage is being studied, including the stage of the global crisis amid a pandemic. The main trends in changes in social communication during a pandemic are analyzed and a forecast is given for further changes in the principles of building trust. The emphasis is on the fact that after the pandemic social trust will be easier to arise in the virtual space than in the physical. The author names the criteria of social trust.

The basic criteria of social trust in modern media communication are considered.
\end{abstract}

Keywords: social communication, social trust, quality of life, win-win strategy, virtual image, virtual communication

For citing: Julia P. Bayer. Social Trust as an Intangible Condition for the Quality of Life: Considering After-Pandemic New Norms // Administrative consulting. 2020. N 6. P. 136-140.

\section{Социальное доверие как нематериальное условие качества жизни: обнуление после пандемии}

\section{Байер Ю. П.}

Российская академия народного хозяйства и государственной службы при Президенте Российской Федерации (Северо-Западный институт управления РАНХиГС), Санкт-Петербург, Российская Федерация; juliabayer@yandex.ru

\begin{abstract}
PЕФЕРАT
В статье рассматривается такой социальный феномен, как социальное доверие, степень изученности этого явления. Дается определение социальному доверию. Социальное доверие рассматривается как один из факторов качества жизни. Изучается трансформация социального доверия от индустриального общества до современного этапа, включая этап глобального кризиса на фоне пандемии. Анализируются основные тенденции изменения социальной коммуникации в период пандемии и дается прогноз дальнейшего изменения принципов формирования доверия. Делается акцент на том, что социальное доверие будет легче возникать в виртуальном пространстве, нежели в физическом. Рассматриваются основные критерии социального доверия в современной медиакоммуникации.
\end{abstract}

Ключевые слова: социальная коммуникация, социальное доверие, качество жизни, стратегия win-win, виртуальный имидж, виртуальная коммуникация

Для цитирования: Julia P. Bayer. Social Trust as an Intangible Condition for the Quality of Life: Considering After-Pandemic New Norms // Управленческое консультирование. 2020. № 6. C. $136-140$.

Nowadays, more and more often we are confronted with reflections and studies on the social or institutional trust, especially when it comes to the relationship between the individual and state. 
I believe that the comfort of living in a particular society is based largely on how it is saturated with people's social trust in each other or whether this trust is absent and, as a result, society and individuals live in it:

- aloof;

- absorbed by bio-survival instincts of fear of deception, loss of money / property / reputation, etc.;

- cautiously and suspiciously establish important interpersonal relationships and contacts. All this, of course, affects the quality of both life itself and the communication in it. And, exploring traditions, studying the changes in the fabric of social communication in modern society, one way or another, we will start with the works of O. Comte and his characteristics of an industrial society, F. Tennis and his "Gemeinschaft und Gesellschaft", E. Durkheim and his typology causality of suicides, especially the anomic type and suicide caused by excessive individualization of the individual, alienation from society.

The formal norms and rules of the modern information society began to supplant spontaneity from public life, the ease of communication, based on mutual trust. Until social networks appeared, for example, the rapid billion-dollar turnover increase in the number of sales of services in Instagram and other social accounts led us to understanding that communication, which puts trust at the forefront, began to gain momentum, forming international communities of interest (individuals easily find like-minded people via hashtags, geolocation ect.), make orders for consulting and coaching, not to mention the sales of goods sold on Instagram platform. In most cases, trust arises based on an analysis of the content of the account, the number of subscribers and publications, comments and responses to them.

We trust the person whose image is created in the virtual space more than an accidental companion in physical space. Politicians and public persons began to urgently hire smm-boxers to run their social networks (as a tool to build voters' trust).

In itself, the topic of social, as well as institutional trust, was raised indirectly in sociology, and as a separate topic, from my point of view, is at the initial stage of study.

The study of social trust, in addition to the works of O. Comte, E. Durkheim, F. Tennis, M. Weber (its value-rational action) is also based on the ideas of B. Barber, N. Luman, P. Shtompki [5], A. Seligmen [3], F. Fukuyama [4], S. Eisenstadt and L. Roniger, as well as on the fresh works of R. Hardin, E. Uslaner, R. Cramer and C. Cook, C. Tilly, M. Dogan, D. Gambetta and H. Hamill.

Social trust as the basis of interpersonal or impersonal business media communication can be defined as a social phenomenon that manifests itself in the interaction of subjects focused on satisfying personal and/or institutional needs (that is, the needs of the social institution to which the individual belongs and which he represents), and also taking into account in this interaction not only his own interest, but also the interest of the addressee of the communication. Such communication is based on the win-win strategy, which a priori is used by both sides. If one of the parties uses the win-lose strategy, then this will destroy the fabric of trust and may lead to the complete cessation of social contact.

For a long time, the win-lose strategy has been successfully used in an industrial depersonalized society, but now, thanks to contemporary social media, it is difficult for an individual / social institution to "just disappear". In this regard, the win-win communication strategy becomes more profitable (not to mention social well-being) when both sides of communication are satisfied. And just such a strategy is the framework for building longterm social trust in society, stability and the ability of its individuals to move from the "biosurvival" mode of existence to a higher level [1].

I believe, in the consciousness of individuals in a society in which communication is imbued with a high level of trust, space is created for creativity and development, which, ultimately, contributes to a higher level of happiness. By happiness we will 
here mean the internal state of calmness and satisfaction, the level of goodwill (as an external indicator of internal well-being) and the subjective estimation feeling of happiness by the individual himself.

Accordingly, we can say that social trust has a direct impact on the quality of the socio-psychological parameter of life. Social trust is also a factor in the stability of society as a whole, covering such a basic need of its members as a sense of security.

Anthony Giddens distinguishes trust in people and trust in "abstract systems". Between people, "trust is built on mutual responsibility and complicity: confidence in the honesty of another is the main source of a sense of honesty and authenticity of oneself. Trust in abstract systems ensures the reliability of everyday life, but by its very nature it cannot replace the reciprocity and intimacy that give personal relationships of trust" [5].

Awareness of the problem of establishing generalized forms of social trust is the same age as modernity itself. The obligation to "fulfill promises" and respect for the will of others is the central point of political theory. The fulfillment of promises, was and is the main thread of which "mutual respect is woven between members of the moral community" [5].

In the contemporary media sphere, we also come across the opinion that in the postmodern subculture the phenomenon of interpersonal trust is absent, but there are only monologues, texts turned into a void.

We agree with P. Shtomka who identifies three main components of a moral society:

1. Trust - P. Shtomka characterizes it as an expectation of good faith behavior of other people in relation to us.

2. Loyalty is an internal imperative not to violate the trust that others endow us with. We can rephrase this - to maintain the existing level of credit of trust and to develop it.

3. Solidarity is a concern for the interests of others and a willingness to take action in their favor, sometimes even to the detriment of one's own interests. What we previously designated as the win-win strategy, although here P. Shtomka went further - we can sacrifice our interests, helping another, facing the win-lose strategy [5].

Thus, we can say that, in terms of the quality of life, we are comfortable living in such a society, whose citizens observe all three points.

A society that is accustomed to living according to its own laws of trust, comfortable for all its members, sometimes may be forced, under the pressure of its new members, to change these laws to less comfortable, more bio-survival than creative ones.

The power of society is often defined by different sociologists as the power of social and interpersonal relationships. Already E. Durkheim emphasized the moral dimension of society: "People cannot live together without consent, and therefore, without making mutual concessions, without strong and lasting ties between themselves" [6]. It was the strength of these social ties that determined, according to Durkheim, the causality of individual suicide in society. Thus, today, when the fabric of social relations is changing, when relationships and communication in virtual reality are added to real relationships, we must pay particular attention to what determines the quality of these relations, and with it the quality of everyday life - trust.

We agree with P. Stomka and R. Inglehart that trust has a special connection with post-materialistic values. Important is the fact established by Inglehart that trust directly affects the quality of life and the subjective feeling of good luck [5]. It is this close relationship revealed by scientists that makes us pay special attention to trust not only as the "oil of modern communication", but also as an intangible component of the quality of life.

Indeed, when residents of a country, city, or village can leave their belongings on the beach, pay in a cafe, in the market, being sure that the culture of the people of hosting them country does not allow them to cheat, the focus of attention shifts, 
namely, we stop living in fear, "bio-survival mode", releasing energy to more elevated emotions of sympathy, friendship, creativity, love, etc., constant tension leaves, a calm atmosphere of friendly communication is created.

In our article, we consider trust as an integral intangible component of the quality of life of any social group in any time period. Meaning the presence of trust - the absence of fear in communication and the willingness to interact kindly, the belief that the communicator will act on the basis of common, not selfish interests.

The time of the coronavirus pandemic during which this article is being written can be called the "nullification of social trust". We are talking about a change in the "vertical" relations of trust between a citizen and the state, and a change in the horizontal fabric of trust between citizens in the physical space. The topic of undermining trust between the citizen and the social institution of the state during the crisis has become more acute. From the point of view of changing the vertical system of trust, namely, the institutional one, between a citizen and the state, we see, in many countries, that in a crisis, the state often acts as a "strict father", while citizens also expect financial and the emotional component of trust, confidence in the future, which during the crisis they did not receive properly from the leaders of states. It seemed that the pandemic took everyone by surprise. The fabric of social trust has become thin.

Considering the pandemic, we can say about lowering the level of trust in the physical space, regardless of the geolocation of citizens. The social distance that we have been accustomed to not observe for many decades, has now been re-created: a distance of 1.5-2 meters, no handshakes (what can we say about hugs and kisses accepted in many countries at a greeting). Fear of getting sick destroyed the trust of physical contacts so long established through socialization.

Nevertheless, it was possible to maintain trust as the fabric of social relations in the virtual sphere, where it increased compensatory, developing during the period of physical distance: the absence of fear of physical contact in this case allowed the development of trust and openness.

Thus, we can conclude that trust and fear are two mutually exclusive socio-psychological phenomena. Where there is fear, there is no trust and vice versa. Nevertheless, only the absence of fear is not a condition for the emergence of trust, but only a necessary prerequisite.

On the way out of the pandemic crisis at all levels of socialization, we will need to think about creating new criteria for trust, mechanisms of socialization and the gradual destruction of fear and mistrust, as well as building a new fabric of social relations.

Let me name the main changes in the principles of media communication and social trust during the global crisis:

1. During a pandemic, social physical distance is offset by increased intense interaction in the virtual space. This trend will continue after the pandemic is over.

2. The system of social (virtual) capital has become the main factor of trust and (in some ways - an analogue of the Chinese Social Credit System) is formed according to a number of parameters that have long been secretly accepted in the world:

- social weight, the ability to influence in society (the number of friends as a factor of trust - common friends, followers in social accounts, i.e. real and potential audience);

- the relevance and significance of topics that the author considers on his/her accounts (politics, healthy lifestyle, creativity, social activities, sale of goods or services);

- the demand for account information in virtual space (the number of likes, comments, advertising orders, the number of commercial transactions completed, in the case of a business account). 
3. Due to the declared and available for validation in the virtual world social capital, social interpersonal trust in the virtual world (especially after the intensified pandemic of fear of personal contact) will arise faster than in physical, and thus, business, interpersonal communication, creating business partnerships of different goals and types, dating, etc. etc. will move to a large extent on virtual platforms. This will be determined not only by the need to justify trust (which is almost completely closed in a virtual environment), but also by the need to remain at a distance with a stranger, prolonged after a pandemic, i.e. - if the contact can be transferred to the virtual sphere - it will be transferred.

Thus, in order to maintain the quality of life and the fabric of social trust in the communication process, the population of all countries, without exception, will continue to move into the virtual sphere, where the system of social capital (credit of trust) will be one of the decisive "trust" parameters.

\section{References}

1. Barber B. The Logic and Limits of Trust. Rutgers University Press, New Jersey, 1983.

2. Luman N. Social systems. Essay on the general theory. SPb. : Nauka, 2007. (In rus)

3. Seligmen A. The Problem of Trust. M. : Ideya-Press, 2002. (In rus)

4. Fukuyama F. Trust. The Social Virtues and the Creation of Prosperity. M. : AST, 2004. (In rus)

5. Shtompka P. Sociology of Social Change. M. : Aspekt Press, 1996. (In rus)

6. Dyurkgejm E. Suicide. M. : AST, 2019. (In rus)

About the author:

Julia P. Bayer, North-West Institute of Management, Branch of RANEPA (St. Petersburg, Russian Federation), Associate Professor of Chair of Social Technologies, PhD in Sociology; juliabayer@ yandex.ru

\section{Литература}

1. Barber B. The Logic and Limits of Trust, Rutgers University Press, New Jersey, 1983.

2. Луман Н. Социальные системы. Очерк общей теории. СПб. : Наука, 2007.

3. Селигмен А. Проблема доверия. М. : Идея-Пресс, 2002.

4. Фукуяма Ф. Доверие. Социальные добродетели и путь к процветанию. М. : ООО «Издательство АСТ», 2004.

5. Штомпка П. Социология социальных изменений. М. : Аспект Пресс, 1996.

6. Дюркгейм Э. Самоубийство. М. : АСТ, 2019.

\section{Об авторе:}

Байер Юлия Паулевна, Северо-Западный институт управления РАНХиГС (Санкт-Петербург, Российская Федерация), доцент кафедры социальных технологий, кандидат социологических наук; juliabayer@yandex.ru 